\title{
OBITUARY PRESENTED IN INDONESIAN NEWSPAPER
}

\author{
Atiqa Sabardila, Adyana Sunanda, Yunus Sulistyono, \\ Dini Restiyanti Pratiwi, dan Agus Budi Wahyudi \\ Universitas Muhammadiyah Surakarta \\ Email: atiqa.sabardila@ums.ac.id
}

\begin{abstract}
The newspaper enables the readers to obtain enlightenment, particularly moral values. Moral values can be obtained through obituary writings. This study was aimed at elaborating the reference, author's perspective, technique of collecting material, role assertion, contribution to writing biography, and motive in the obituary. The data were obtained through a documentation technique while the data source was attained from the printed version of the called Kompas Indonesia newspapers from 2015 to 2017. The newspaper was the only one in the country giving this special rubric. The study applied the referential identity method, marker reading technique, and pragmatic identity analysis as well as pedagogic and hermeneutic approach. Results show that the obituary texts in the newspaper are potential to become a learning material in Indonesian language education, particularly in the elementary school. The inspirational figures can further impact on students' character building.
\end{abstract}

Keywords: obituary, character building, motives, reference, Kompas

\section{PEMBERITAAN OBITUARI DALAM SURAT KABAR INDONESIA}

\begin{abstract}
Abstrak
Surat kabar memungkinkan pembaca mendapatkan pencerahan, khususnya nilai-nilai moral. Nilai-nilai moral dapat diperoleh melalui penulisan berita kematian di surat kabar. Penelitian ini bertujuan untuk menguraikan referensi, perspektif penulis, teknik mengumpulkan bahan, peran peran, kontribusi untuk menulis biografi, dan motif dalam berita kematian. Data diperoleh melalui teknik dokumentasi; sementara sumber data diperoleh dari surat kabar cetak bernama Kompas Indonesia pada 2015-2017. Sumber data hanya diambil dari koran Kompas mengingat bahwa Kompas satu-satunya koran yang menyediakan kolom mengenai isu ini. Penelitian ini menggunakan metode identitas referensial dan teknik marker reading. Analisis data dilakukan dengan menggunakan metode referensial, teknik membaca penanda, dan metode identitas pragmatis serta pendekatan pedagogik dan hermeneutik. Berdasarkan analisis data yang disajikan dalam artikel ini, teks berita kematian berpotensi menjadi bahan pembelajaran dalam pendidikan bahasa Indonesia, khususnya di Sekolah Dasar. Tokoh-tokoh inspirasional dapat lebih jauh berdampak pada pembentukan karakter siswa.
\end{abstract}

Kata kunci: obituari, pembentukan karakter, motif, referensi, Kompas 


\section{INTRODUCTION}

Kompas, one of the Indonesian popular printed newspapers, consistently presents obituary to some passed-away inspirational figures. As this article's main data, it reveals the reference, author's perspective, the technique of collecting material, role assertion, contribution to writing biography, and motive in the obituary. The published figure in the column is the media own right. Based on the initial observation to the newspaper, it evidences the heterogeneity. Therefore, the obituary in the newspaper varies from bureaucrats, scientists, artists, and religious leaders as well.

In order to build students' behavior or capacity, various methods can be implemented. Therefore, this investigation offers one of the methods of the implementation through the obituary. This article proves the breadth of the topics can be investigated from obituaries. Furthermore, this becomes essential when a certain figure has not been productively written yet. There are other specifications about the obituary: an article that can be read at glance as straight news. This means that it can be taught easily to upper-class students started in elementary school, class V and VI in order to improve their writing skills.

The newspaper enables the readers to obtain enlightenment, particularly moral values. The education cannot be conveyed if they read an announcement of people's death only. In the announcement of people's death, their journey in building their carrier will never be elicited. This missing piece is the most significant part that can be generated for a character education. The readers acquire a concrete learning since the character lives in a real-world context. By loading a lot of moral values to the readers of the newspaper, it can be followed up to writing text-book materials; the position of the obituary is prioritized as the supplementary readings.

If a short story, novel, or romance describe more than one characters in the stories with diverse-unique characters, the discourse of the obituary only offers one character. Thus, the learner becomes can focus on it, else they read a lot of obituaries. The more they read, the more value they gain through reading the obituary. Hence, it becomes very important to collect obituaries for mapping many excellent figures in their own personality.

Based on the study of the internal and external elements of the discourse of obituary, Sunanda, et al. (2017) explained the internal and external elements of the discourse. Their study showed the specification and preference to the development of Indonesia language learning materials which refer to the concept of politeness as reflected in the discourse of the obituary. The discourse of obituary has its own specific characteristic in its compilation. In terms of its internal elements, the type this text refers to the pattern of the development of the discourse which is easy to follow and integrated so that it can be easily understood to serve as the source of the reference Indonesian language materials. In the meantime, the external element that refers to the external aspect of the obituary has a tendency to emphasize the aspect of politeness. It is 
like what has been found by Aremu (2011) who is researching an obituary in terms of socio-pragmatics. The obituary as the data source was in Nigerian English. He saw that the obituary in Nigerian English has its characteristics of a euphemism, metaphors, idioms, hedges, mixed code, code, and lexical borrowing. His study concluded that the use of the social language was a mixture of the two types of representation of language, i.e. English and Nigeria. Then, Kearl (1986-1987) explained that the presence of obituary described the social stratification and one's status in their work of the moment of his death, the way of his death, institutional affiliation and time of her death. Matcha (19941995) investigated obituaries from respondents aged over 65 years associated with the age when he got married, the wedding, the number of children and their descendants, marital status, and family patterns. Fernandes (2006) concentrated on euphemistic in the style of obituaries in the $19^{\text {th }}$ century.

This study is able to be an alternativescientific work that can strengthen the backdrop in writing Indonesian language teaching and learning the material as its main purpose. This study aimed at elaborating the reference, author's perspective, the technique of collecting material, role assertion, contribution to writing biography, and motive in the obituary. This contribution becomes relevant and important facing the result of the study that underlies the character building which is suitable to the Indonesian language and education curriculum.

\section{METHOD}

The method for collecting the data was performed by documentation method, i.e., the documenting Kompass which specifically publishes the discourse of obituary. The data source was taken from the newspaper that was published in 2015 - 2017. A span of three-years gives the availability of the data to be analyzed because of the emergence of a discourse of the obituary is not possibly predicted since the events that are written in the discourse is after someone's death. The data source is only drawn from the newspaper Kompas since Kompas is the only newspaper that gives a special column on the issue. Moreover, based on the reading of the newspaper, it is proved that the discourse of the obituary issues more diverse background with the different profession, which is beneficial for the readers who are heterogeneous. The discourse of the obituary is also delivered with a mild language that begins to be digested by the students at the elementary school level.

This study applies a referential identity method and marker reading technique. The first method is applied to unveil the content of a message on the obituary as well as the subject popularized in titling the obituary. In this step, we look at the obituary texts and interpret the message within the texts. In addition, we look at the titling to see the subject character who were being potrayed. In the second method, we applied analyses to describe the author's point of view and the technique of collecting the material in building the obituary texts. Furthermore, this current study utilizes a hermeneutic technique to interpret the content of the 
contribution of the obituary in writing biography and motives in it.

\section{RESULTS AND DISCUSSION}

\section{Result}

In accordance with the focus, the results of the study include references, author perspectives, material gathering techniques, roles, contributions to writing biographies, and motives in obituaries. The complete research results are presented in Table 1.

\section{Discussion}

\section{Reference of the Obituaries in Kompas}

Based on the analyzed obituary, journalists of Kompas are said to have represented Indonesian society in their way of building obituary texts. There is conformity between the perception of community members with them. This may occur in the way they position themselves as the community members that feel and judge the journey of the figures when they are actively involved in any social environments. Excerpt 1 below provides an example of an obituary text in Kompas 19 August 2015.

\section{Excerpt 1:}

"Mantan Dirut Pertamina Berpulang" (K, 19/8/2015)

'Former Director of Pertamina Dies'

Tabel 1. Representation of Obituary News

\begin{tabular}{|c|c|c|}
\hline Aspect & Element & Example \\
\hline \multirow[t]{5}{*}{ Reference } & Who & The President Director \\
\hline & What & Died, leaving a wife \\
\hline & When & $\begin{array}{l}\text { Tuesday morning; Wednesday }(19 / 8) \\
08.00 \text { o'clock; and 2002-2004; and } 2011\end{array}$ \\
\hline & Where & Mount Elizabeth Hospital, Singapore \\
\hline & Why & (because of) cancer of the lymph nodes \\
\hline Point of view & Third person & $\begin{array}{l}\text { Locomotive role-model figure of } \\
\text { democracy; 'The protector and loyal } \\
\text { Comrade; Senior Journalists }\end{array}$ \\
\hline \multirow[t]{2}{*}{ Collecting material } & Observation & $\begin{array}{l}\text { With all his action, the leaving of Adnan } \\
\text { Buyung putting grief for many people }\end{array}$ \\
\hline & Interview & $\begin{array}{l}\text { According to the second daughter of the } \\
\text { deceased }\end{array}$ \\
\hline Popularized Role & $\begin{array}{l}\text { Social organization, } \\
\text { profession, bureaucracy }\end{array}$ & $\begin{array}{l}\text { Directors, lawyers, economists, politicians, } \\
\text { artists, journalists, scientists, comedians }\end{array}$ \\
\hline Contributions & $\begin{array}{l}\text { obituaries can be a matter } \\
\text { of learning }\end{array}$ & $\begin{array}{l}\text { The role from various- inspirational } \\
\text { figures becomes inspirational }\end{array}$ \\
\hline Motives & $\begin{array}{l}\text { Maintaining the situation } \\
\text { for the bereaved family }\end{array}$ & $\begin{array}{l}\text { The presented news is about the time of } \\
\text { passing away, cause, when the lights of } \\
\text { specifications, and the funeral held. }\end{array}$ \\
\hline
\end{tabular}


Table 2. Reference of the Obituaries

\begin{tabular}{cl}
\hline Elements & \multicolumn{1}{c}{ Example } \\
\hline Who & $\begin{array}{l}\text { Direktur Utama PT Pertamina (persero) 2004-2006; Widya Purnama; Almarhum; } \\
\text { sosok inspiratif bagi insan Pertamina; atau Widya } \\
\text { 'The President Director of PT Pertamina (Persero) 2004-2006; Widya Purnama; The } \\
\text { deceased; inspirational figure for employees of Pertamina; or Widya' }\end{array}$ \\
What & $\begin{array}{l}\text { Meninggal, meninggalkan seorang istri (...); dimakamkan; lahir; menjabat sebagai } \\
\text { Direktur Utama PT Indosat Tbk; dan menjabat Komisaris Independen PT } \\
\text { Perusahaan Gas Negara Tbk. }\end{array}$ \\
& $\begin{array}{l}\text { 'Died, leaving a wife (...); buried; born; served as President Director of PT Indosat } \\
\text { Tbk, and served as independent Commissioner of PT Perusahaan Gas Negara Tbk. }\end{array}$ \\
When & $\begin{array}{l}\text { Selasa pahing, Tabu (29/8) pukul 08.00; dan 2002-2004; dan 2011 } \\
\text { Tuesday morning; Wednesday (19/8) 08.00 o'clock; and 2002-2004; and 2011 } \\
\text { Rhere }\end{array}$ \\
$\begin{array}{l}\text { Rumah sakit Mount Elizabeth, Singapura; pemakaman umum Layur, Rawamangun, } \\
\text { Jakarta Timur } \\
\text { 'Mount Elizabeth Hospital, Singapore; public funeral Largehead Hairtail, } \\
\text { Rawamangun, East Jakarta' } \\
\text { (lantaran) sakit kanker getah bening } \\
\text { '(because of) cancer of the lymph nodes' }\end{array}$ \\
\hline
\end{tabular}

\section{The Author's Point of View}

Narratives about the figure are developed in the obituary based on third person point of view. This contrasts with the news discourse developed in Kompas. If their position as a news writer, as in the straight news, they potentialize the perspective of the third person and first person. The third person point of view is marked by pronouns he/she, they, the given name, or the combination of a relative clause and pronouns, the given name and the extension with the mention of instances of a person's place of work, or profession (Sabardila, 2017).
Excerpt 2 below describes the use of titles, greetings, and pronouns associated with the narrated-preached figures. As it pertains to people who already passed away, the story is conveyed by using the third person points of view, and greetings. Their salutations are obtained based on their work or recognition around them. Their special greetings are such as the late and the bodies (deceased).

\section{Excerpt 2:}

The following table elaborates the use of the titles, callings, greetings, and the use of pronouns in the obituary. 
Table 3. The Author's Point of View

\begin{tabular}{|c|c|c|}
\hline No. & Figure & The title, Calling, Greetings, and The use of Pronouns \\
\hline 1. & $\begin{array}{l}\text { Widya } \\
\text { Purnama }\end{array}$ & $\begin{array}{l}\text { Mantan Dirut Pertamina, Almarhum, Papa (sapaan dari anak mereka), Widya, } \\
\text { dan sosok inspiratif bagi insan Pertamina } \\
\text { 'Former Director of Pertamina, deceased, papa (greetings from their } \\
\text { children), Widya, and inspirational figure for employees of Pertamina' }\end{array}$ \\
\hline 2. & $\begin{array}{l}\text { Adnan Buyung } \\
\text { Nasution }\end{array}$ & $\begin{array}{l}\text { Advokat senior, jenazah, Abang, "lokomotif demokrasi, tokoh panutan, pejuang hak } \\
\text { asasi manusia (yang jujur, berintegritas, dan profesional), dan pengacara besar yang } \\
\text { punya prinsip } \\
\text { 'senior advocate, brother, "locomotive role-model figure of democracy, } \\
\text { human rights, fighters (who is honest, has integrity, and professional), and a } \\
\text { great lawyer who got the principle' }\end{array}$ \\
\hline 3. & Fahmi Myla & $\begin{array}{l}\text { Sang Pengayom dan setia kawan, purnakarya wartawan Kompas, Fahmy, } \\
\text { almarhum, sosok (yang ramah, tidak pernah marah, mengayomi, dan setia kawan), } \\
\text { pekerja (keras, tak banyak bicara, dan baik), dan wartawan yang tidak pelit ilmu } \\
\text { 'The protector and loyal Comrade, the former journalist of Kompas, Fahmy, } \\
\text { deceased, a figure (which is friendly, never angry, trial and loyal friend), } \\
\text { workers (hard, not too much talking, and good), and the journalists that are } \\
\text { not stingy to science' }\end{array}$ \\
\hline 4. & $\begin{array}{l}\text { Pande Radja } \\
\text { Silalahi }\end{array}$ & $\begin{array}{l}\text { Ekonom senior dari lembaga riset Center for Strategic and International Studies, } \\
\text { almarhum, Pande, Pronomina ia, peneliti, seorang intelektual yang rendah hati, } \\
\text { akademisi lulusan dari Jepang, figur yang memiliki integritas dan komitmen, } \\
\text { beliau, komisioner KPPU, penasihat ahli Kapolri, dan jenazah almarhum } \\
\text { 'Senior Economist from Centre for Strategic and International Studies, the late, } \\
\text { Pande, the pronouns he, researchers, humble intellectual, academics } \\
\text { graduates of Japan, a figure that has integrity and commitment, he, } \\
\text { Commissioner of KPPU, expert advisors of Indonesian Police Corpse, } \\
\text { deceased' }\end{array}$ \\
\hline 5. & Drs. Suyadi & $\begin{array}{l}\text { Pak Raden, Ekonom, pencipta tokoh Si Unyil dalam serial TV tahun 1980-an, } \\
\text { maestro sketsa dan legenda dongeng, beliau, Suyadi. } \\
\text { 'Pak Raden, Economist, creator of Si Unyil in the 1980's TV series, maestro } \\
\text { of sketches and tales, legends, and Suyadi' }\end{array}$ \\
\hline 6. & $\begin{array}{l}\text { Slamet Effendy } \\
\text { Yusuf }\end{array}$ & $\begin{array}{l}\text { Guru Kader NU, Slamet, Almarhum, Panglima Barisan Ansor Serbaguna, Wakil } \\
\text { Ketua PBNU, politisi ulung, aktivis, wartawan, anggota SPR dari Golkar periode } \\
1992-2009, \text { guru kader, dan pribadi yang berdedikasi untuk NU, Islam, dan negara } \\
\text { Teacher of NU Cadres, Slamet, the late Panglima Barisan Ansor } \\
\text { Serbaguna, Vice Chairman of PBNU, eminent politician, activist, } \\
\text { journalist, member of SPR of period 1992-2009 period, teachers of cadres, } \\
\text { dedicated person to NU, Islam, and the country' }\end{array}$ \\
\hline 7. & Suhardiman & $\begin{array}{l}\text { Tokoh Golkar, pendiri Central Organisasi Karyawan Swadiri Indonesia, Pak } \\
\text { Suhardiman, beliau, dan tokoh paling senior dan menjadi tempat bertanya kader } \\
\text { Golkar } \\
\text { 'Figures of Golkar, founder of the Central Organization of Employees } \\
\text { Swadiri Indonesia, Pak Suhardiman, he, and the most senior figure and } \\
\text { place for cadres of Golkar to ask' }\end{array}$ \\
\hline
\end{tabular}




\begin{tabular}{|c|c|c|}
\hline No. & Figure & The title, Calling, Greetings, and The use of Pronouns \\
\hline 8. & Ben Anderson & $\begin{array}{l}\text { Profesor emeritus Universitas Cornell Amerika Serikat, Benedict Richard O'Gorman } \\
\text { Anderson, pengkaji Indonesia, Ben, Indonesianis legendaris, pengarang buku Imagined } \\
\text { Communities (1983), jenazah Ben, dan pronomina dia } \\
\text { 'Professor Emeritus at the Cornell University United States, Benedict Richard } \\
\text { O'Gorman Anderson, researcher of Indonesia, Ben, the legendary-Indonesianist, } \\
\text { the author of Imagined Communities (1983), Ben, and a pronoun he' }\end{array}$ \\
\hline 9. & Zaili Asril & $\begin{array}{l}\text { Wartawan senior asal Sumatra Barat yang sebelumnya pernah bergabung dengan } \\
\text { Harian Kompas, Sutan Zaili Asril, Zaili, pengusaha asal Sumbar, sosok ayah yang } \\
\text { mendidik anaknya dengan keras, tetapi dalam arti positif, pronomina beliau, sosok } \\
\text { pembelajar, jurnalis intelek, sosok kritis, seorang wartawan yang menekankan agar } \\
\text { seorang kuat dan berwawasan. } \\
\text { Senior Journalists from West Sumatra who had previously joined the } \\
\text { Daily Kompas, Sutan Zaili Chen, Zaili, a businessman from West Sumatra, } \\
\text { father who educates his son hard, but in a positive sense, the pronouns he, a } \\
\text { figure of learner, intellect journalist, a critical person, a journalist who } \\
\text { stressed that one must be strong and insightful ' }\end{array}$ \\
\hline 10. & $\begin{array}{l}\text { Boutros- } \\
\text { Boutros-Ghali }\end{array}$ & $\begin{array}{l}\text { Pemimpin di Masa Sulit, diplomat kawakan Mesir yang memimpin Perserikatan } \\
\text { Bangsa-Bangsa dalam masa-masa sulit, pronomina dia, sekretaris ke-6 PBB, } \\
\text { Menteri Luar Negeri Mesir (1977, 1978-1979), Sekteraris PBB pertama dari Benua } \\
\text { Afrik pada } 1 \text { Januari 1992, akademisi dengan spesialisasi hukum internasional, dan } \\
\text { sekjen PBB dengan satu masa jabatan } \\
\text { 'Leaders in tough time, an Egyptian diplomat who led the United Nations } \\
\text { in difficult times, the pronouns he, Secretary of the United Nations, the } \\
\text { Foreign Minister of Egypt (1977, 1978-1979), the first secretary of UN from } \\
\text { Africa on } 1 \text { January 1992, academics specializing in international law, and } \\
\text { UN general secretary with a period of working' }\end{array}$ \\
\hline 11. & Ahmad Watik & $\begin{array}{l}\text { Tokoh Muhammadiyah sekaligus salah seorang pendiri Ikatan Cendikiawan Muslim } \\
\text { Indonesia, Ahmad Watik Pratiknya, almarhum, dokter ahli anatomi, anggota Majelis } \\
\text { Tabligh Pimpinan Pusat Muhammadiyah (1985-1990), sekretaris presiden ketiga } \\
\text { Republik Indonesia BJ Habibie tahun 1998-1999, dan pencetus peta dakwah } \\
\text { Muhammadiyah Figures and the founders of the Muslim Scholar Indonesia } \\
\text { Bonds as well, Ahmad Watik Pratiknya, deceased, a medical doctor of an } \\
\text { anatomist, Member of Assembly of the Tabligh Muhammadiyah Board } \\
\text { Center (1985-1990), the third secretary of President of the Republic of } \\
\text { Indonesia B.J. Habibie in 1998-1999, and initiator of peta dakwah' }\end{array}$ \\
\hline 12. & Jus Badudu & $\begin{array}{l}\text { Sang Pahlawan Bahasa, pakar bahasa yang mengatakan bahwa bahasa Indonesia } \\
\text { adalah bahasa malaikat karena keberadaannya di tengah-tengah bangsa yang } \\
\text { sangat bhineka sangat menakjubkan, Jusuf Syarif Badudu, penerima Satyalencana } \\
\text { Karya Satya (1987), Bintang Mahaputera Nararya (2001), dan Anugerah Sewaka } \\
\text { Winayaroha (2007), pronomina dia, Almarhum, dan menjadi guru sejak berusia } \\
15 \text { tahun dan baru berhenti pada usia } 80 \text { tahun. } \\
\text { 'The hero of language, the language experts who say that the Indonesian } \\
\text { language is the language of the angels since its existence in the midst of a } \\
\text { diverse nation, Jusuf Sharif Badudu, recipient of the Satya Lencana Karya } \\
\text { Satya (1987), Bintang Mahaputera Nararya (2001), and the grace You } \\
\text { Winayaroha (2007), the pronouns he, deceased, and a teacher since he was } \\
15 \text { years and recently stopped at the age of } 80 \text { years' }\end{array}$ \\
\hline
\end{tabular}




\begin{tabular}{|c|c|c|}
\hline No. & Figure & The title, Calling, Greetings, and The use of Pronouns \\
\hline 13. & $\begin{array}{l}\text { Umar Anggara } \\
\text { Jenis }\end{array}$ & $\begin{array}{l}\text { Tokoh Bioétika, Kepala lembaga Ilmu Pengetahuan Indonesia peiode 2202-2010, } \\
\text { Prof. Dr. Umar Anggara Jenie, Umar, Bapak, tokoh iptek yang berjasa pada } \\
\text { lembaga, pengembangan riset dan iptek di Indonesia, pronomina ia, Ketua Komisi } \\
\text { Bioetika Nasional 2009-2012, dan anggota International Dialogue on Beoethic of } \\
\text { European Group on Ethics of Sciences and New Technology } \\
\text { 'Figure of Bioétika, head of the Lembaga Ilmu Pengetahuan Indonesia } \\
\text { 2002-2010, Prof. Dr. Umar Umar Anggara Jenis, Mr, science and } \\
\text { technology developer of Indonesian research, technology and science, the } \\
\text { pronouns he, Chairman of the National Bioethics Commission 2009-2012, } \\
\text { and member of the International Dialogue on Bioethics of the European Group } \\
\text { on Ethics of Science and New Technology' }\end{array}$ \\
\hline 14. & Kusmanto & $\begin{array}{l}\text { Pelawak Bambang Gentolet, komedian kawakan Indonesia, Jenazah Bambang, } \\
\text { Almarhum, Bapak, Bambang, Bapak (orang yang tekun dengan pengabdiannya } \\
\text { pada seni lawak), dan pembawa acara dalam acara-acara hajatan atau perusahaan. } \\
\text { ' Comedian Bambang Gentolet, a legendary comedian Indonesia, } \\
\text { Almarhum Bambang, father, Bambang, a father (a man who is diligent with } \\
\text { his devotion on the art of humor), and emcee in celebration events or } \\
\text { company' }\end{array}$ \\
\hline
\end{tabular}

The third person points of view (: he, she, or he) and their substitutions clarify the characteristics of the obituary as a means to writing biography. Then, the choice of greetings late, and corpse are dictions developed in the obituary.

The journalists' knowledge towards the figures may possibly affect the nuance of the obituary. They add much information that is assessed objectively so that the death of the figure will deliver any wisdom to the readers. In the meantime, since there is no interest, publics are satisfied with the figures.

Identification of the role, profession, and salutation, if appointed to be a creative writing material, are able to enrich students on how to avoid monotonous writing. In addition to the pronouns (he, she, or he), the replacement can be in the form of taking the title, rank, or other words which are grammatically replaceable the personal names. The replacement, as in table 1 , is able to avoid the monotonous delivery.

\section{The Technique of Collecting Material}

The technique of collecting material in this article is conveyed by the observation and interview. The marker marking that the writing is drawn from the results of the interview is indicated by the mention of news sources (such as the second daughter of the deceased (Annisa Purnama), President Joko Widodo, the wife of the deceased, Arni Sultan, and Prasodjo Suyadi, assistant of Suyadi) and the marker according to or said and and their synonymy. Excerpt 3 and 4 below show an examples of the material collection.

\section{Excerpt 3:}

"Menurut putri kedua almarhum, Annisa Purnama (24), sebelum dirawat di RS Mount Elizabeth, almarhum dirawat di $R S$ 
Pertamina Jaya, Jakarta". ("Mantan

Dirut Pertamina Berpulang", K, 19/8/2015)

'According to the second daughter of the deceased, Annisa Purnama (24), before being treated at the Mount Elizabeth Hospital, the deceased was hospitalized in Pertamina Jaya Hospital, Jakarta." (Former CEO of Pertamina Passed Away", K, 19/8/2015)

\section{Excerpt 4:}

Dengan segala kiprahnya, kepergian Adnan Buyung meninggalkan duka bagi banyak pihak. "Bang Buyung tokoh panutan, pejuang hak asasi manusia yang jujur, berintegritas, dan profesional," kata Presiden Joko Widodo (Pejuang Hukum yang Punya Prinsip). (K, 25/9/2015)

"With all his action, the leaving of Adnan Buyung putting grief for many people." Bang Buyung is a role-model, who has integrity, and professionalism, "said President Joko Widodo. ("Legal Combatants who Had Principles" (K, 25/9/2015)

Sunanda, et al. (2017) states that there is an element form the discourse of the obituary, namely testimonial. A testimonial is a witness, the certificate (which can be worn as witnesses) (Kamus Besar Bahasa Indonesia, 2009:873). In the discourse (a) three informants presented to give testimony. So, journalists have not only raised their own knowledge or insights, however, strengthen their writing by presenting witnesses.

\section{The Popularized Role}

The role of the figures refers to activity when in social organization, profession, or in the bureaucracy. The following specifications are attached to each character elicited in Kompas.

(1) Mantan Dirut Pertamina (Widya Purnama)

'Former Director of Pertamina (Widya Purnama)'

(2) Pejuang Hukum yang Punya Prinsip (Adnan Buyung)

'Fighter of Law who Has Principle (Adnan Buyung)'

(3) Ekonom (Pande Silalahi) 'Economist (Pande Silalahi)'

(4) Pak Raden (Drs. Suyadi) 'Pak Raden (Drs. Suyadi)'

(5) Tokoh Golkar (Suhardiman) 'Figure of Golkar (Suhardiman)'

(6) Wartawan (Zaili Asril) 'Journalist' (Zaili Asril)'

(7) Sang Pahlawan Bahasa (Jus Badudu) 'The Hero of Languange (Jus Badudu)'

(8) Tokoh Bioétika (Umar Anggara Jenie)

'Figure Bioétika (Umar Anggara Jenie)'

(9) Bambang Gentolet (Kasbianto) 'Bambang Gentolet (Kasbianto)'

Towards the reported losses and grieves, the authors see the success of the career, such as former "Director of Pertamina". The other examples are such as the success in the firmness or the fighter of law that has principle, the protector and loyal friend, a leader in hard times, and teacher of NU cadres, as the accentuates professionalism, skills, or skills such as Economist, figure bioethics, 
(skillfully in giving) lectures, journalist, language, heroes, and comedian.

\section{Contributions of Obituary to Biography Writing}

There is no neutral ground in writing history. However, journalists write about the losses is described objectively about their carrier. It is firmed that people are the informant about the figure. A study by Ondimu (2014) about a socio-cultural understanding of death in Kenyan newspaper suggests that the way journalists build obituaries reflects the society in which a genre of obituary can be established.

By not being concentrated in specific areas, Indonesian obituaries can be a matter of learning, especially about the biography. By knowing their carrier and way of life, the successor in each field is able to study by understanding the role of the character. The role from variousinspirational figures becomes inspirational for the people who have similar and potential talent.

To reach a certain position, a figure manages to demonstrate a superior personality. Therefore, journalists often supplement their obituaries by demonstrating the nature of the personality of the figure through the testimony of any figures' close-friends or their families.

Some of them are starting to write the obituary by performing a series of data collection, by interpreting the documentation method, interviews and/ or observation about the place where the figures ever live in. Such biographies generally raise the alive and productive figure. However, one could commence from the utilization of obituary. Hence, the character will be written is already dead. Thus, from the limited data, then it is developed into a complete writing.

Why is it still very feasible for writing a biography? Back into the process of achievement that readers want to get the story of steadfastness in achieving goals or achievements of the figure. With the guidelines, the readers can picture concretely. The biography of which originated from the utilization of these obituaries tend to be oriented in the disclosure of all attitude and personality of the figure to achieve success.

The character exemplified in this article was obtained from their characters, namely (1) Widya Purnama, his is inspiring for the employees of Pertamina, (1) Pande Radja Silalahi who is down to earth, honest and committed, and kept actively developing their knowledge, (2) Pak Raden who educated children through Indonesian stories "Unyil", (3) Suhardiman, the place for asking and has a powerful political instinct, (4) Ben Anderson, a critical and productive writer about Indonesia that his lectures is greatly admired by the students of Indonesia from different areas, (5) Zaili Asril who educated his son hard so that is not too easily giving up and complain, working on something maximally, critical and bold, trying to enlighten and educate people, and keep learning, (6) Jus Badudu who managed the difference the nation of Indonesia, productive, and diligently on perfecting his writing, (7) Umar Anggara Jenis who diligently worked in accordance with the field of his expertise, and (8) Bambang Gentolet who is diligent in his devotion to the arts of humor. 


\section{Motives in Obituary}

The opinion built by the journalist seems to prefer the save delivering, then it is presented at the same time as the passed away of someone. Nagy (2017) looks at a changing nature of death and mourning through Hungarian obituaries. In this study he concludes that Hungarian obituaries prefer death taboo to be put as an empirical context in a number of ways. Instead of signifiying death taboo, metaphorical expressions of death show a secular demystified, but not tabooed relationship towards death. This is different from common Indonesian obituaries. Furthermore, in writing a biography authors are positioned as an open work which can be scrutinized. Indonesian journalists who adhere to a religion are guided by the teachings of the religion, i.e. if aroused to talk about a person who is deceased, choose the good things which can be imitated, not the dishonor or lack of them. This is in accordance with the exposure of Khalid (1973:19) which cites the opinion of Ibn Al-Qayyim.

"Pengejekan dan pencelaan atas saudaramu sesama Muslim karena perbuatan dosa yang ia lakukan akan lebih besar durhakanya ketimbang dosanya [dosa pembuat dosa tadi]. Dengan ejekan yang engkau lontarkan itu berarti meneriakkan dengan lantang ketaatan dan kesucian serta menyerukan bahwa dirimu bebas dari dosa dan kesalahan" (Khalid, 1973:19).

"Mocking at your Muslim fellows because of their sin that they did is greater sin over their sin. With the mocking that you cast, it means shouting aloud about obedience and chastity as well as calling for yourself free from sin and mistake." (Khalid, 1973:19).

The situation is a of suffering. In this situation, the society from any culture applies the maxim of wisdom, which is awarded to members of the family who are grieving by keeping in a situation that does not hurt the feelings of them. Therefore, the presented news is about the time of passing away, cause, when the lights of specifications, and the funeral held.

The newspaper Kompas is not simply opening up space for the announcements or advertisements, but also provides a column for learning, especially values that can be picked due to the death of a figure.

Something that appears in the title or in the body of the discourse is something that provides benefits for the reader because the figure spoken in the field specification possession described investments. In fact, through writing the obituary of the journalist has managed to reaffirm the lights and the specifications they have. A productive and professional journalist producing works that apparent qualities that contributed news with the emphasis on objective content and language that is good and right. With the proclamation of the specification of the role of the community-owned characters, readers gain knowledge about personality that could follow from the character.

Obituary of Compass serves as a greeting or a title variation in accordance 
with their professional. Excerpt 4 below provides examples of titles of obituaries.

\section{Excerpt 4:}

(1) "Mantan Dirut Pertamina Berpulang" (K, 19/8/2015)

"Former President
Pertamina passed away" (K,
$19 / 8 / 2015)$

(2) "Pejuang Hukum yang Punya Prinsip" (K, 25/9/2015)

"Fighters who have a Legal Principle" (K, 25/9/2015)

(3) "Perginya Sang Pengayom dan Setia Kawan" (K, 5/10/2015)

"The Leaving The Protector and Loyal Friend" (K, 5/10/2015)

(4) "Ekonom Pande Radja Silalahi Tutup Usia" (K, 3/10/2015)

"Economist Pande Radja Silalahi Dies" (K, 3/10/2015)

(5) "Pak Raden Berpulang" (K, 31/10/2015)

"Pak Raden Passed Away" ( $K$, 31/10/2015)

(6) "Guru Kader NU itu Telah Berpulang" (K, 4/12/2015)

"The Teacher of NU Cadres Has Passed Away" (K, 4/12/2015)

(7) "Tokoh Golkar Suhardiman Meninggal" (K, 14/12/2015)

"The Figre of Golkar Suhardiman Died " $(K, 14 / 12 / 2015)$

(8) "Kuliah Terakhir Ben Anderson" (K, 14/12/2015)

"Last Lecture of Ben Anderson" (K, 14/12/2015)

(9) "Wartawan Zaili Asril Tutup Usia" (K, 13/1/2016)

"Journalists Zaili Asril Died" ( $K$, $13 / 1 / 2016)$

(10) "Ben-Boutros-Ghali, Pemimpin di
Masa Sulit" (K, 18/2/2016)

"Boutros-Boutros-Ghali, a Leader in Hard Times" (K, 18/2/2016)

The acceptability of the writing of obituary is wider compared to the writing of biography. A biography is generally structured to "advertise the figure" that will be prepared for a new career. If so, when negative things felt could interfere with these goals, the sides will not be rendered. The author of the biography will follow them who order it. The acceptability of the biography is not always smooth. Those who are a priori from the beginning will be difficult to accept the presence of the book. Obituary writing materials excavated on the initiative of the journalists. Therefore, the intervention of people near the figure, who has been unable to direct the content of writing of the obituary. They remain as the connoisseur of the writings, as other readers who don't have any closeness of the relationship, either as colleagues or blood relations. If so, the obituary is more objective because the journalists hear or consider how communities behave towards the figure he is writing. The valid (correct) data is achieved through a short interview to become the material for the preparation of the title and the exposure in the body of the discourse.

The contribution of the presence of the obituary perceives the wisdom of the death of a figure. In addition, because of the expertise or skills, they have a number of personalities that led him to the position. A society that will get them example can grow and develop the 
personality so they are ready to follow the careers and expertise of the figure that is aligned with their field of expertise. Through the death of a prominent journalist, he wants to give the enlightenment to the readers about the advantages of such a figure that is not only related to his achievements but also possession of excellence of his character. The journalist information about the death of a figure is expected to elicit the more and more new generation. The phrase "one fallen, thousands blossoming" could be clarified with the inserts a sort of "missing one (figure); grow a thousand (new other figures). The mass media serves to broaden the ownership of the value, including the value that was carried out by a figure who died.

Example (1a) informs that Widya Purnama, an inspiring figure for employees of Pertamina continually dedicated and committed to providing the best for the company and the state.

(1a) "Almarhum adalah sosok yang inspiratif bagi insan Pertamina untuk senantiasa berdedikasi dan berkomitmen memberikan yang terbaik tidak hanya bagi perusahaan, tetapi juga bagi negara." (K, 19/8/2015)

"The deceased was an inspiring figure for the people of Pertamina to continually dedicate and commit to providing the best not only for companies but also for the state". ( $K$, 19/8/2015)

Example (2a) inform Adnan Nasution, jars, which became a widely admired figure, fighters for human rights who is honest, has integrity, professional, and have a principle.

(2a) "Bang Buyung tokoh panutan, pejuang hak asasi manusia yang jujur, berintegritas, dan profesional." Kata Presiden Joko Widodo. Almarhum pengacara besar yang punya prinsip." Ujar Wakil Presiden Jusuf Kalla dalam perjalanan menghadiri Sidang Umum PBB di New York, AS." (K, 25/9/2015)

"Buyung is a role model, the honestfighter of human rights, having integrity, and professionalism." Says President Joko Widodo. The deceased was a huge lawyer who had principle." Says Vice President Jusuf Kalla on the way to General Assembly of UN in New York, US.” (K, 25/9/2015)

Example (3a) informs that Fahmi Myala, friendly-figure, a never angry person, and a loyal friend. In addition, he was a hard worker, did not talk too much, respectful, and revered.

(3a) Dahlan Kadir, Ketua Serikat Penerbit Surat Kabar Sulawesi Selatan, mengenang almarhum sebagai sosok yang ramah, tidak pernah marah, mengayomi, dan setia kawan." "... orangnya pekerja keras, tak banyak bicara, dan baik. Walau kami berbeda media, kesetiakawanan beliau sangat bagus. Inilah yang membuat ia disegani dan dihormati." ... "Herman Hafsah, wartawan Metro TV, juga mengenang Fahmy sebagai wartawan yang tidak pelit ilmu, pengayom, dan jarang marah." (K, 5 /10/2015) 
"Dahlan Kadir, the Chairman of South Sulawesi newspaper, in memory of the deceased as a friendly figure, never angry, trial, and loyal friend." "... Dahlan was a hard worker, not talkactive, and kind. Despite our different media, solidarity, he was very good. This is what makes Dian respected and revered. "... "Herman Hafsah, reporter of Metro TV, also in memory of journalists who are not as Fahmi stingy science, pengayom, and rarely get angry." (K, 5/10/2015)

Example (4a) informs that Pande Radja Silalahi is an economist, intellectual humility, which has integrity, commitment, and active in any seminars.

(4a) Menurut Djisman, almarhum adalah seorang intelektual yang rendah hati. Almarhum semasa masih hidup termasuk figur yang memiliki integritas dan komitmen. ... Menurut Anton, ia sempat bertemu dengan Pande dalam suatu seminar dua hari lalu. "Beliau aktif terus. ...(K, 3/10/2015)

According to Djisman, deceased, was an intellectual figure and humble. ... during his life alive, he was a figure who has integrity and commitment. ... According to Anton, he met Pande in a seminar two days ago. "He actively joined to any seminars. ...(K, 3/10/2015)

Example (5a) informs that Pak Raden's real name is Drs. Suyadi. He was the maestro of sketches and legends of fairy tales that created Unyil, in 1980's television series, who was committed that the television shows can educate children of Indonesia.

(5a) "Suyadi lahir di Puger, Kabupaten Jember, Jawa Timur, 28 Nopember 1932. Ia menciptakan tokoh Si Unyil agar terdapat acara televisi yang mendidik anak-anak Indonesia (K, 31/10/2015)

"Suyadi was born in Puger, Jember Regency, East Java, November 28 $8^{\text {th }}$, 1932. He created a character Unyil so there is a TV show that educating children of Indonesia ( $K$, 31/10/2015)

Example (6a) informs that Slamet Effendi Yusuf is an eminent politician, activist, journalist, and teachers of NU cadres. In addition, he dedicated himself to NU, Islam, and the state.

(6a) "Ia dikenal sebagai politisi ulung, aktivis, dan wartawan. Ia menjadi anggota MPR dari Golkar tahun 1987-1992 dan anggota $P R$ selama tiga periode 19922009." .. "Di masa orang-orang dekatnya, Slamet dianggap sebagai guru kader. "Hampir semua di PBNU saat ini kader beliau". Kata Helmy. "Menurut Ketua Umum Partai Persatuan Pembangunan versi muktamar Surabaya Romahurmuzy, Slamet sabar dan mau memberikan wawasan kepada "adik-adiknya" di NU. "Mas Slamet itu pribadi yang berdedikasi untuk NU, Islam, dan Negara" kata Hanif Dhakhiri, Menteri Ketenagakerjaan." (K, 4/12/2015).

"He is known as an eminent politician, activist, and journalist. He became a member of Golkar's MPR 1987-1992 period and House members during 
three periods of 1992-2009. “ ... "in the eyes of his close friends, Slamet is considered as the teacher of cadres. "Almost all of the current cadres are in him," Helmy said. "According to the Chairman of Persatuan Pembangunan Party, version of the Muktamar of Surabaya, Romahurmuziy, Slamet is patient and willing to give insight to his younger brothers in NU. "Slamet was personally dedicated to NU, Islam, and the state, "said Hanif Dhadiki, Minister of Employment." ( $K, 4 / 12 / 2015)$.

Example (7a) informs Suhardiman, the figure of Golkar, which was the place for cadres of Golkar to ask and has a powerful political instinct who states that Jokowi-Kalla will win the presidential election in 2014.

(7a) "Suhardiman yang lahir di Solo, Jawa Tengah, 16 Desember 1924, menurut Bambang, selama ini merupakan tokoh paling senior dan menjadi tempat bertanya para kader Golkar. "Beliau juga memiliki insting politikyang kuat. Jauh hari sebelum pemilihan presiden 2014, Pak Suhardiman menyatakan, "Jokowi-Kalla akan menang" (K, 14/12/2015).

"Suhardiman, who was born in Solo, Central Java, December $16^{\text {th }}, 1924$, according to Bambang, he is the most senior figure and the place for Golkar cadres to ask." He also has a strong political instinct. Far before the 2014 presidential election, Mr. Suhardiman said, "Jokowi-Kalla will win." (K, 14/12/2015).
Example (8a) informs Benedict Richard O'Gorman Anderson, a professor emeritus of Cornell University, United States, who came to Indonesia related to the his book publication entitled Di Bawah Tiga Bendera: Anarkisme Global dan Imajinasi Antikolonial 'Under the Three Flags: Anarchism and the Global Imagination of Anti-Colonial' which his lecture was attended by hundreds of students from various areas. Through the subtitle obituary ("critical thinking") it explains that Ben has critical thinking, i.e. the concept of hating the pretense in Indonesia that forces eliminating the diversity with uniformity.

(8a) "Kuliah umum yang mengupas anarkisme dan nasionalisme itu dihadiri ratusan mahasiswa dan pengagum Ben dari berbagai daerah... "Pengarang buku Imagined Communities (1983) ... "Dari penelitiannya, dia menerbitkan Analisis Awal Kudeta 1 Oktober 1965 di Indonesia ... "Karya Ben terkait Indonesia, antara lain, adalah Java in a Time of Revolution: Occupation a Resistance 1944-1946 (1972), Imagined Communities: Reflections on the Origin and Spread of Nationalism (1983), dan Language and Power: Exploring Political Cultures in Indonesia (1990). Guru Besar Antropologi Universitas Gadjah Mada PM Laksono menuturkan, Ben membenci konsep kepura-puraan di Indonesia (K, 14/12/2015).

"Public lecture that discussed the anarchism and nationalism was attended by hundreds of students and admirers of Ben from different areas... "Author of Imagined Communities (1983)... "From his research, he 
published an Analysis Awal Kudeta 1 Oktober 1965 di Indonesia ..." Ben's works related to Indonesia are such as the Java in a Time of Revolution: Occupation an Resistance 1944-1946 (1972), Imagined Communities: Reflections on the Origin and Spread of Nationalism am (1983), and the Language and Power: Exploring Political Cultures in Indonesia (1990)... "Professor of Anthropology, Gadjah Mada University PM Laksono said, Ben hated the concept of pretention in Indonesia $(K, 14 / 12 / 2015)$.

Example (9a) describes that Zaili Asril, journalist of Kompas, who became an author and entrepreneur. He was a figure of the father who educated his son hard in order to not to easily give up and complain, doing something maximally, brave, a figure of intellect, critical journalists and bold, try to enlighten and educat people, and kept learning.

(9a) "Ayahanda adalah sosok ayah yang mendidik anaknya dengan keras, tetapi dalam arti positif. Kami dididik agar tidak gampang menyerah dan mengeluh atas persoalan yang sedang dihadapi. Beliau selalu mengingatkan agar dalam kehidupan sehari-hari, kami mengerjakan segala sesuatu secara maksimal, ...".

"Zaili sosok pembelajar. Jurnalis intelek yang waktu senggangnya dimanfaatkan untuk membaca dan diskusi. Ia juga sosok kritis dan berani untuk tidak disukai banyak orang. Tulisannya mengkritik, tetapi tetap memberi solusi dan pandangan"

"Dalam setiap diskusi almarhum selalu membahas bagaimana cara agar kita tetap mencerahkan dan mencerdaskan orang lain. Itu juga yang membuatnya sampai saat ini terus belajar." ... (K, 13/1/2016)

"Father was a figure who educated his son hard but in a positive sense. We were trained not to easily give up and complain over the issue at our hand. $\mathrm{He}$ always reminded so that in everyday life, doing everything maximally, ...". "Zaili was a learner. The intellectual journalist that his spare time was utilized for reading and discussion. $\mathrm{He}$ was also a critical figure and brave to be disliked by many people. His writings were criticizing but still, give the solution and view "...

"In any discussions, the deceased always discusses how to keep remaining to enlighten and educate others. It also makes it so far keep learning. "... $(K, 13 / 1 / 2016)$

Example (10a) inform BoutrosBoutros-Ghali, former Foreign Minister of Egypt (1977; 1978-1989), which played an important role in the Camp David agreement and became the SecretaryGeneral of the United Nations (1992). He's wild-eyed praised his successor who led the UN in its most challenging, and Calderon: in history, who dared ask tough questions on the members of the UN and confirmed the independence of the office and the Secretariat as a whole. He was an academic specializing in international law.

(10a) "Kepemimpinannya dikenang oleh penerusnya, sekjen PBB Ban Ki Moon. Dia memuji pendahulunya yang telah memimpin PBB melalui "salah satu masa 
paling rusuh dan menantang dalam sejarah". Dia memperlihatkan keberanian dalam mengajukan pertanyaan sulit pada negara anggota, dan menegaskan independensi jabatannya dan sekretariat secara keseluruhan(K, 18/2/2016).

"His leadership is remembered by his successor, UN Secretary-general Ban-KiMoon. He praised his predecessor who had led the UN through "one of the most challenging, and Calderon period in history". "He showed courage in asking tough questions to the Member States, and asserted the independence of the office and secretarial as a whole," said Ben. (K, 18/2/2016).

The contents of the obituary that accentuates the role of character, either formal or informal character, become an additional material in a biography if the journey of the figure has already been published. It says an addition if the book will be reprinted. By this information, the writing of biography, especially those who have died, becomes more completely since there is information about the activity of the figure in the past or towards the end of his life.

As a column that gives a tribute to the deceased, journalists implicitly provide non-formal education to the people about someone's personal life and career as well as their excellent form until he is positioned as figures.

By including various figures showing their respective specifications, the author of obituary managed to meet the diversity of interests of the people in Indonesia. The author of obituary understands that Indonesia society does need to be "matured" through the lights of potential local, national, and global figure.

Learning from other's personality has been proposed by Myers and Briggs (2017). In their book, they state that the profile of the figures who are able to find their job based on their own personality. Obituary provides figures who are close to the readers and their journey is concretely recognized by the readers.

In speaking skills, especially speaking Indonesian, a number of character values are obtained (Supriyadi, et al., 2017). If reading skills are developed, from reading, such as Hamka poetry, character education is obtained (Solihati, 2017). Through reading activities children will get social value stability (Muhammadi, et al., 2018). Thus, from language skills obtained a number of values that are important for the maturity of one's personality. The same thing certainly applies to someone who reads the obituary.

\section{CONCLUSIONS}

The description finds that the content of obituaries meets the element of $5 \mathrm{~W}+$ $1 \mathrm{H}$. Therefore, Obituary is classified as straight news. Elements of 'who' reveals the names of the people who die, 'what' reveals the profession or role in the institution/community, 'when' reveals the time they die, their illness, when they pioneer and end their career, 'where' they die, where they initiate - end his career, funeral, and the cause (why) of uncovering the events leading up to the end of their life, and 'how' to uncover the procession of cemetery. Since it is written to gain the wisdom of them, the element of 'who' and 'what' get more exposure. 
The figures are discussed in various ways, such as the mention of their title, greeting, or attributes that are in accordance with the character they have already built. Everything can be summed up using a third person point of view. Their titles are according to their ability, achievement, or superiority that have been formed and gained. They have specific greeting/calling, namely the mention of the deceased or his/her remains.

The collection of the material is obtained by interview(s). This is marked by the use of the verb says or forward according to. This technique is the fastest way for the journalists to build the obituary. The authors of obituary present their writings with the emphasis on the personality, career (: toughness, persistence, solidarity, or protecting), or upholding the professionalism or skills.

Further, this research finds that obituary is the types of text that can represent the way of Indonesians appreciate the ones who have passed away, regardless of issues that might have impacted the subject's characters that are being portrayed. In addition, this way of presenting obituaries are very likely to be a lesson to be learned within teachinglearning contexts. Thus, this type of writing may be used at schools.

The journalists write the specification of roles or skills of the figures who were preached. The writing of obituary can complement an existing biography or it can be a stub that needs to be developed. In addition to writing material about an obituary, it can be proposed to become Indonesian Language textbook learning materials, particularly in higher grade (elementary school grades 5 and 6).

\section{ACKNOWLEDGEMENTS}

Acknowledgments submitted to the minister of education and culture which has financed application of highly education applications (PTUPT).

\section{REFERENCES}

Afful, J. B.A. A Genre Analysis of Death Announcements in Ghanaian Newspapers. Department of English, Faculty of Arts. University of Cape Coast, Cape Coast, Ghana.

Aremu, M. A. (2011). A Social Pragmatic Analysis of Obituary Announcements in English in Nigeria. Journal of the Nigeria English Studies Association (JNESA), 14 (2), 132-143. https:// www.semanticscholar.org/paper/ASocial-Pragmatic-Analysis-OfObituary-In-English-Aremu-Alayand e/8b119644464f2002a50c2dd4374d7 $49 \mathrm{a} 0 \mathrm{e}$.

Fernandes, E. C. (2006). Language of Death: Euphemism and Conceptual Metaphorization in Victorian Obituaries. SKY Journal of Linguistics, 19: 101-131. https://www. re s e a r c h gat e. ne t/ publication/242383248_The_ Language_of_Death_Euphemism_ and_Conceptual_Metaphorization_ in_Victorian_Obituaries.

Hani Al-Hajj. (2005). 1001 Kisah Teladan. Jakarta: Pustaka Al-Kautsar. Cetakan Ketiga.

Depdikbud. (2009). Kamus Besar Bahasa Indonesia. Jakarta: PT Media Pustaka Phoenix. Kompas. Indonesian national daily newspaper.

Kearl, M. C. (1986-1987). Death as A Measure of Life: A Research Note on The Kastenbaum-Spilka Strategy 
of Obituary Analyses. Omega, 17(1), 65-75. https://journals.sagepub. com/doi/10.2190/R9D1-QJQ9NTVJ-54T6.

Khalid, K. M. (1973). Ahlullah: Menapak Jenjang Menuju Taman Hati: Surabaya: Rízala Gusti.

Matcha, D.A. (1994-1995). Obituary Analysis of Early $20^{\text {th }}$ Centure Marriage and Family Patterns in Northwest Ohio. Omega, 30(2), 121130. https://journals.sagepub.com/ doi/abs/10.2190/2PDL-XE6FKDY5-RX4T?journalCode=omea.

Muhammadi, Taufina, \& Chandra. (2018). Literasi Membaca untuk Memantapkan Nilai Sosial Siswa SD. Litera Jurnal Bahasa, Sastra, dan Pengajarannya. 17(2), 202-212. https://journal.uny.ac.id/index. $\mathrm{php} /$ litera/article/view/16830

Myers \& Briggs. (2017). Pribadimu Profesimu: Temukan Karier yang Sempurna untuk Anda Berdasarkan Tipe Kepribadian. Jakarta: PT Gramedia.

Nagy, Z. (2018). The Changing Nature of Death and Mouring - An Analysis of Hungarian Obituaries (1961-2000). Mortality. 23(2), 151-172. DOI: 10.1080/13576275.2017.1322053.

Nugroho, E. A., Dwi Y., Siti Khanafiah. (2013). Pembuatan Bahan Ajar Komik Sains Inkuiri Materi Benda untuk Mengembangkan Karakter Siswa Kelas IV SD. Unnes Physic Educational Journal, 2(1), 60-68. DOI: https://doi.org/10.15294/ upej.v1i2.1379.

Ondimu, J. (2014). A Socio-Cultural Understanding of Death: A Genre Analysis of Obituaries in A Kenyan
Newspaper. Language Matters, 45(1), 3-22. DOI:10.1080/10228195.2013. 805799.

Sabardila, A., Wijana, I.D.P., Suhandano. (2017). Packaging Differences of News Content on Title. Humaniora, 29(1), 94-107. DOI: https://doi. org/10.22146/jh.22570.

Soetantyo, S.P. (2013). Peran Dongeng dalam Pembentukan Karakter Siswa Sekolah Dasar. Jurnal Pendidikan, 14(1), 44-51. DOI: 10.33830/jp. v14i1.355.2013.

Solihati, N. (2017). Aspek Pendidikan Karakter dalam Puisi Hamka. Litera Jurnal Bahasa, Sastra, dan Pengajarannya, 16(1), 51-63. DOI: https://doi.org/10.21831/1tr. v16i1.14250

Sudaryanto. (1993). Metode dan Aneka Teknik Analisis Bahasa. Yogyakarta: Duta Wacana University Press.

Sumaryadi. (2016). Estetika Lakon Ketoprak Senapati Pinilih Karya Bondan Nusantara dan Relevansinya bagi Pendidikan Karakter. Disertasi. Fakultas Ilmu Filsafat Universitas Gadjah Mada, Yogyakarta.

Sunanda, A., Atiqa S., Wahyudi, A.B., Sulistyono, Y. (2017). Identifikasi Pola Unsur Internal dan Eksternal Wacana Obituarium Surat Kabar Indonesia. ICoLLiT. April 2017. http://hdl.handle.net/11617/8924.

Supriyadi, \& Siti NS. (2017). Nilai-nilai Karakter dalam Pembelajaran Keterampilan Berbicara Bahasa Indonesia pada Siswa SMK. Litera Jurnal Bahasa, Sastra, dan Pengajarannya, 16(2), 228-248. DOI: https://doi.org/10.21831/1tr. v16i2.14050 